\title{
The British Women's Liberation Movement in the 1970s: Redefining the Personal and the Political
}

Le mouvement britannique pour la libération des femmes dans les années 1970: Redéfinir le personnel et le politique

\section{Florence Binard}

\section{(2) OpenEdition}

\section{Journals}

Electronic version

URL: http://journals.openedition.org/rfcb/1688

DOI: $10.4000 /$ rfcb. 1688

ISSN: 2429-4373

Publisher

CRECIB - Centre de recherche et d'études en civilisation britannique

Electronic reference

Florence Binard, «The British Women's Liberation Movement in the 1970s: Redefining the Personal and the Political », Revue Française de Civilisation Britannique [Online], XXII- Hors série | 2017, Online since 30 December 2017, connection on 30 April 2019. URL : http://journals.openedition.org/ rfcb/1688; DOl : 10.4000/rfcb.1688

This text was automatically generated on 30 April 2019.

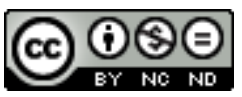

Revue française de civilisation britannique est mis à disposition selon les termes de la licence Creative Commons Attribution - Pas d'Utilisation Commerciale - Pas de Modification 4.0 International. 


\title{
The British Women's Liberation Movement in the 1970s: Redefining the Personal and the Political
}

\author{
Le mouvement britannique pour la libération des femmes dans les années 1970: \\ Redéfinir le personnel et le politique
}

Florence Binard

1 Historians and founders of the British Women's Liberation Movement (BWLM) consider that the year 1970 marked the start of the movement (Sally Alexander, Françoise BarretDucroq, Barbara Caine, Martin Pugh, Lynne Segal, Sheila Rowbotham). They mention two major events that took place that year: the first BWLM Conference in Oxford from 27 February to 1 March which gathered between 500 and 600 participants, many more than expected, and the protest against a Miss World beauty competition held in London on 20 November which brought the attention of the movement into the public and media arena. ${ }^{1}$ It is to be noted, however, that the BWLM was influenced by and took place within a context of diverse contestation movements that had emerged in the 1960s in Britain, parts of Europe and also in the United States (Student Revolution, Sexual Revolution, Campaign for Nuclear Disarmament (CND), Civil Rights Movement, Hippie Movement, Gay Rights). As underlined by historians, the publication in 1963 of Betty Friedan's best seller The Feminine Mystique ${ }^{2}$ had a profound influence on second-wave feminism in the United States but also in Britain. ${ }^{3}$ The book was a virulent condemnation of the consumer society that fed the myth of the fulfilled housewife and mother, making women prisoners of their homes and depriving them of their lives. As Betty Friedan put it:

The feminine mystique has succeeded in burying millions of American women alive.

There is no way for these women to break out of their comfortable concentration camps except by finally putting forth an effort - that human effort which reaches beyond biology, beyond the narrow walls of home, to help shape the future. ${ }^{4}$

In the USA, The Feminine Mystique and its author contributed to the creation, in 1966, of the National Organization of Women (NOW) and more generally of the AWLM whose modes of actions and organisation inspired British feminists. ${ }^{5}$ Both the concept of 
"consciousness-raising" and the slogan "The personal is political" which were central in the British WLM, first appeared in the United States. ${ }^{6}$ But, if it is undeniable that the American WLM was crucial to the development of the BWLM, the latter was not simply an offshoot of the American movement, it had its own home-grown specificities and differed in a number of ways. Whereas the American movement was heavily influenced by the civil rights movement and led by white liberal middle-class women on the one hand and by radicals who placed the emphasis on sexual liberation on the other, the BWLM emerged, to a large extent, from the British New Left, from Socialist and Marxist groups in which women's issues had often been dismissed as personal ones. ${ }^{7}$

\section{Women's growing dissatisfaction}

3 Forty years after gaining the right to vote on an equal footing with men, ${ }^{8}$ British women felt that equality between the sexes was still a long way off. In the political, economic and social fields, things had barely changed since the 1920s, women were grossly underrepresented in Parliament, access to many professional jobs continued to be restricted, unequal pay was still legal, in universities women made up only a quarter of the student population. But perhaps even more crucial, cultural attitudes and beliefs were still very backward despite important changes in women's lives. Mentalities were patriarchal and, based on retrograde values, women's freedoms were restricted. For instance, such practices that would now be deemed shocking as forbidding access to Wimpy bars ("ancestor" of MacDonald's) to unaccompanied women after $11 \mathrm{pm},{ }^{9}$ or refusing women mortgages if they did not have the backing of male guarantors, were common. The dominant view was that women's 'natural' role was to care for children at home, that men were the breadwinners, and that money earnt by women was pin money. However, these legal and social practices that were keeping women in subordinate positions were increasingly perceived as unfair and outdated especially by women.

The Ford women's strike in Dagenham in June 1968 is an example of women's growing awareness of the blatant injustice that affected them and which marked a turning point in the fight for equal pay. When the Minister of Employment, Barbara Castle, became involved in the conflict she was "outraged"10 to discover the injustice of the pay grading in many industries. Indeed, at the time male factory workers were classified into categories based on their skills but there was an additional category for women, 'the women's grade" which meant that female workers earned $85 \%$ of the male rate. However, the end result of the strike was a partial victory for women as the increase in pay achieved was still only $92 \%$ of the men's rate. Thus, although the strike paved the way for the 1970 Equal Pay Act, its outcome showed that society was not quite ready to recognise full equality between the sexes.

5 The view that men and women should not be treated on an equal footing on account of their sexual differences and the belief that women's place was primarily that of the homemaker spanned the social and political spectrum. Yet, for women, this imposed outlook was becoming increasingly dissatisfying and many were feeling discontented with their lives. Thanks to technological progress and the mass production of modern appliances such as fridges, washing machines, electric stoves etc. the burden of their household chores was substantially reduced leaving free time available to women. Perhaps an even more important development was the medical advances and the laws passed in the 1960s relating to contraception and abortion which meant that women were 
now able to fully control their fertility. ${ }^{11}$ As Sheila Rowbotham stated: "It was ignored that it was rather naive to expect women to fulfil some abstracted 'natural' function in a most unnatural society particularly when contraceptives were reducing the time women were spending in childbirth". ${ }^{12}$ For feminist Ann Oakley this evolution meant profound lifestyle changes for many women who came to realise that "the so-called consequences of the reproductive division between the sexes" [were] no longer a 'natural' destiny, that they [had] become outdated in so far as couples [could] "choose when they [should] have babies, and who [should] feed them". ${ }^{13}$ She argued that technology had altered the impact of biology thus enabling a redefinition of the conceptions of femininity and masculinity. In her ground-breaking book, Sex, Gender and Society (1972), she defended the idea of distinguishing between sex and gender:

'Sex' is a word that refers to the biological differences between male and female: the visible difference in genitalia, the related difference in procreative function. 'Gender' however is a matter of culture: it refers to the social classification into 'masculine' and 'feminine.'. ${ }^{14}$

6 This theorisation which was shared by the majority of feminists in the early $1970 \mathrm{~s}^{15}$ has proven crucial to the development of feminism and gender studies ever since. Women became aware that their subordinate position to men was not determined by so-called natural traits but mostly due to conditioning through unequal social structures. They were realising that there are no fundamental differences between the sexes bar those concerned with reproduction and this growing awareness that the "feminine destiny" was a myth led them to question their positions on both political and personal grounds. The BWLM was a national movement that gathered its strength from its grassroots at local level, through the creation and existence of thousands of women's groups throughout the country. It was characterised by a myriad different types of public actions led by women that ranged from demonstrations, protest marches, strikes to music festivals, artistic events or drama performances; from workshops to conferences, that were heavily publicised and analysed thanks to a flourishing multifaceted feminist press. It lasted over a decade until the early 1980s when it lost its impetus under the conservative government of Margaret Thatcher but there is no denying that it has had profound long term impacts on mentalities, especially on the way women see themselves and are seen in society.

\section{Women's Liberation and left-wing sexism}

7 The fact that the BWLM started with a conference that took place at Ruskin College in Oxford is quite significant regarding the socialist stance of British feminists but also in view of the development of Women's Studies that followed. Founded in 1899, the College " aimed to provide university-standard education for working class people to empower them to act more effectively on behalf of working class communities and organisations such as trade unions, political parties, co-operative societies and working men's institutes". ${ }^{16}$ In 1970, this left-wing positioning was still very much the ethos of the College and several of the main organisers of the conference had links to Ruskin. Sally Alexander, who was at the forefront of the BWLM and co-organiser of the conference had qualified for admission to Ruskin "because [she] had left school at fifteen and was a trade union member with no independent means of support". ${ }^{17}$ Also, the conference, co-initiated by socialist feminist Sheila Rowbotham, ${ }^{18}$ was intended to be a women's history conference ${ }^{19}$ and had its origins in a pamphlet she had entitled "Women's Liberation and the New Politics" first 
published in 1969 in the underground left-wing paper, Black Dwarf . ${ }^{20}$ But if the location of the first BWLM Conference at Ruskin College in Oxford, was a reflection of the left-wing political positioning of the movement, the event also marked the distancing of the women's movement from left-wing organisations and groups. As Sheila Rowbotham pointed out: "Propaganda for domestic bliss did not only come from the right. 'Left-wing' sociologists stood firm on the sanctity of the family". ${ }^{21}$ Indeed, although resistance to women's emancipation was much stronger among those on the political right, the issue extended beyond party politics as feminists soon recognised. The fact that when the idea of working on women's history had been put forward at a Ruskin History Workshop, in 1969, it was greeted with laughter by the male audience ${ }^{22}$ showed that sexism ran rampant across the political spectrum. The vast majority of British feminists described themselves as socialists and believed that feminism was inseparable from socialism, however, many grew disillusioned with their male 'comrades' who paid lip service to feminism and promised equality once the revolution was achieved but who showed no inclinations whatsoever to treat women on an equal footing with men in the meantime. Many, like Sheila Rowbotham or Sally Alexander had come to realise that they needed to create their own organisations to address women's issues. Their analyses led them to place the 'sacrosanct' family at the heart of the capitalist exploitation of women but also as the foundation unit of patriarchal society and therefore of women's oppression and exploitation by men:

Although in need of protection from different circumstances, both working-class and middle-class men combine to secure their sanctuary. The condition of the preservation of the 'ideal' family as of the 'ideal' fuck are definitions of female nature which are not only imposed, but imposed in order to maintain the interest men have in finding compensation from the exploitation and alienation capitalism forces on them at work. ${ }^{23}$

8 The Night Cleaners' Campaign between 1970 and 1973 was a blatant illustration of the fact that the exploitation of women workers was both gender and class based. As underlined by George Stevenson, despite the support of the Cleaners Action group (CAG), composed of cleaners, women's liberationists, and socialists, male trade unionists and the trade unions were reluctant to give their full support to the cleaners. In many ways their approach to women's work reflected their sexist views: "In a repeat of those arguing the Dagenham women were working for 'pin money', the TGWU [Transport and General Workers' Union] perceived the strikers as women before they were workers". ${ }^{24}$

9 In a special issue of the feminist magazine, Shrew, women were encouraged to unionise despite the acknowledged shortcomings of the unions regarding women's issues:

Some people are very critical of unions. They say they are bureaucratic and only concerned to improve wages. Also, the structure of unions tends to exclude women from the executive, so the particular interests of women are not considered.

We recognise that unions have many limitations, and that these limitations are most obvious in the case of women workers. However, to join a union is still the necessary first step if women are going to get better conditions at work. ${ }^{25}$

10 Although issues of race and racism were given much more attention in the United States than in Britain, they were not ignored. Like American first and second-wave feminists, British feminists compared women to Black people. They argued that both had been brainwashed into believing that they were naturally and biologically suited to menial tasks and that their happiness was found in subordinate positions: "If you're black, working class and a woman, you lose out three times over" ${ }^{26--}$ 
11 The Grunwick Strike which lasted nearly two years, from August 1976 to July 1978 and whose aim was to obtain the right to unionise is another example of the limits of trade union support to women workers. It is presented as "one of the most important and significant strikes of the 1970s" on the site of the Working Class Movement Library (WCML), ${ }^{27}$ it is also remembered as the first industrial dispute involving mainly women of colour. Led by Jayaben Desai and Kalaben Patel, a group composed mainly of female Asian workers dissatisfied with the way they were treated by the management of the firm, went on strike and demanded the right to join a union. Although they had the support of rank and file unionists, the dispute ended with the defeat of the strikers because the leadership of the TUC and APEX (Association of professional Executive, Clerical and Computer Staff) retreated from mass picketing and withdrew their support ${ }^{28}$ leaving the women, once again, disillusioned with trade unions. As Amrit Wilson underlined:

At Grunwick this unity of the working class was achieved. Hundreds of trade unionists came day after day to support the Grunwick strikers on the picket line. But in the end it wasn't enough because they hadn't the courage to confront and defy the handful of men who control the trade union bureaucracy. The white working class had been weakened by their dependence on these leaders. ${ }^{29}$

12 Many feminists from the women's movement also gave their support on the picket line and were welcome by the strikers but interestingly many women of colour did not want the "help" of white "libbers" in other domains concerning their communities. They felt that it was up to them to find their own path to emancipation and that this emancipation would not necessarily mean that they should become westernised:

I think the predominantly white women's movement would be of very little use to Asian women in their struggles to liberate themselves as women. They can support them in their other struggles, and are sometimes doing so. For example, during the Grunwick strike white feminists have gone out there day after day and helped with picketing. That is the sort of support they could give to Asian women. On the other hand, if they try to solve Asian women's problems for them in their communities it will make their relationships with Asian women very bad, and achieve nothing. Because it would be patronising interference and would be seen as such. ${ }^{30}$

13 Although the first Black women's group was formed in Brixton in 1973, British black feminism really developed in the late 1970s and early 1980s. In 1979 the newly formed Organisation of Women of Asian and African Descent held a conference in Brixton, London, which gathered nearly 300 Black women from several big cities (Birmingham, Brighton, Coventry, Leeds, London, Manchester and Sheffield). The conference insisted on the necessity for an autonomous Black Women's Movement in Britain to address issues specific to Black women who were treated as second-class citizens and suffered a triple oppression that was "ignored by male-dominated Black groups; by white-dominated women's groups; and by middle-class-dominated left groups". ${ }^{31}$ This alliance of women of colour was rooted in their common experience as victims of colonialism and imperialism which, according to them, outweighed their ethnic and cultural differences. One example of such common experience was the new immigration laws and the practice of humiliating virginity tests for fiancées to join their future husbands.

The support of socialist feminists to working class women who in the late 1960s had organised strikes for equal pay and were, thereby, instrumental in the rise of secondwave feminism in Britain was an important aspect of the BWLM, but the need for a more global perspective on women's oppression soon appeared and was to be discussed during conferences. 


\section{WLM Conferences}

The outcome of the first conference was the adoption of four demands that were branded as the programme of the BWLM: they were printed on badges, written on banners, placards and shouted during demonstration marches: (1) Equal pay for equal work, (2) Equal education and equal opportunities, (3) Free contraception and abortion on demand, (4) Free 24 hour nurseries.

16 The main objective was to target women's oppression at its core. Getting married and having children was identified as the principal cause of women's subordination because it meant that women (who were deemed to be "natural" domestic carers) came, as housewives, under the male financial control of their husbands. The 24-hour nurseries, sometimes presented or understood as an anti-family measure, as a way for women to forsake their motherly duties, was in fact intended to provide free childcare for women whenever they needed it, for instance for women working shifts. Among feminists, it was widely agreed that the family should not be the primary responsibility of women, that domestic duties should be shared equally between men and women, that just as men were, women should be entitled to financial independence. They also defended the idea that their bodies were their own and although access to contraception and abortion had been greatly facilitated by the laws passed in the 1960s, there were still battles to be fought on that front, all the more so as in the mid-1970s, James White, a Labour MP sponsored a bill to tighten access to abortion.

This first conference was followed by numerous local and regional conferences ${ }^{32}$ but also by seven national conferences that were held in different cities throughout Britain ${ }^{33}$ and which gathered hundreds and even thousands of women. ${ }^{34}$ These conferences were organised in a bottom-up manner in that as many local groups as possible were represented and final decisions were taken at the end during plenary sessions. At the 1974 national conference in Edinburgh, two demands were added to the first four: (5) Legal and financial independence for all women and (6) the right to a self-defined sexuality, an end to discrimination against lesbians. And at the Birmingham national conference in 1978, a seventh demand was adopted: (7) Freedom for all women from intimidation by the threat or use of male violence, an end to the laws, assumptions and institutions that perpetuate male dominance and men's aggression towards women. ${ }^{35}$ The suggestion (put forward by radical feminists among whom were sheila Jeffreys and Sandra McNeill) that this $7^{\text {th }}$ demand should replace all six previous demands on the grounds that nothing could be gained from a patriarchal state and that men were the enemy, triggered a heated debate. Divisions that had grown over the years came to a head and the conference became the stage of raw and bitter arguments between the socialist feminists who insisted that capitalism and patriarchy accounted for women's social and financial inferiority and the radical/revolutionary feminists for whom male supremacy and women's experiences of sexuality and violence were the roots of women's oppression". ${ }^{36}$ Because all attempts at structuring the movement had been crushed from the start and as the BWLM had remained totally non-hierarchical in its organisation, it meant that there was no mechanism for controlling such an unruly situation. Yet, as the movement grew, diverging views developed and the divide between socialist feminists and radical feminists appeared more and more irreconcilable. The idea that women as a class should free themselves from the tyranny of male aggression by becoming political 
lesbians ${ }^{37}$ and by creating safe separate spaces for women was met with strong negative reactions from socialist feminists. The Birmingham conference ended in chaos and noone dared organise another one after such an experience. It was the last national conference and it marked the end of a united BWLM. As noted by historian Barbara Caine:

By the 1980s, the very suggestion that there could be one unified feminism was deemed prescriptive and exclusionary and there was an increasing tendency to recognize, and even endorse, diversity through the use of the plural 'feminisms' rather than of any singular 'feminism'. ${ }^{38}$

\section{Laws}

The scope and the strength of the movement was such that the government could not ignore the demands of the feminists and was forced to take actions. The movement thus contributed to major transformations of institutions through the passing of landmark laws ${ }^{39}$ notably: The Equal Pay Act of 1970 that came into force in $1975 ;{ }^{40}$ The Employment Protection Act of 1975 which made provisions for the protection of pregnant women in terms of maternity leave and pay; The Sex Discrimination Act of 1975 which aimed to promote equality between women and men and to provide equal opportunities to both sexes. It also established the Equal Opportunities Commission (EOC) to which grievances could be taken in case of unequal treatment; The Domestic Violence and Matrimonial Proceedings Act of $1976^{41}$ which enabled married women to obtain a court order against their husbands; The Housing Act (Homeless Persons) of 1978 which provided accommodation for battered wives. Although there is no denying that these laws led to substantial improvements to women's lives and established the principle of equality between men and women, they fell short of women's expectations. For instance, women were angered at the way authorities were dealing with violence against women as in the case of the "Yorkshire Ripper crisis" in Leeds, which lasted five years between 1975 and 1980. The recommendations given to women, which consisted in advising them to avoid going out alone at night, highlighted the lack and inadequacy with which the State responded to such issues.

19 By the end of the 1970s many feminists were disillusioned with the ability or will of the State to effect real change as it was clear that there were many loopholes and that law enforcement was inadequate. ${ }^{42}$ Employers soon found ways to avoid equality by altering the job contents so that comparisons between men and women's work could not be done. It was not until 1984 that wage parity was achieved for the Ford workers in Dagenham ${ }^{43}$ and today British women still earn less than men: the overall gender pay gap is $13.9 \%$ according to the Fawcett Society. ${ }^{44}$ The Domestic Violence Act did not apply to unmarried women and did not include such violence as marital rape which only became illegal in 1991..$^{45}$ Above all, despite further legislation, violence against women has remained widespread as shown by the 2014-15 Crown Prosecution Service Violence against Women and Girls crime report. ${ }^{46}$

\section{Women's groups and Consciousness-raising}

of equal importance to the battles for legal advancements was the profound consciousness-raising impact of the BWLM on individual women and, subsequently, on society at large. As noted by Sheila Rowbotham, the WLM seemed to appear from 
nowhere ${ }^{47}$ and yet, for many, it seemed long overdue. One explanation as to why it took so long for a movement to emerge was that it was difficult for women to consciously recognise that they were oppressed, that the dissatisfaction many felt was not caused by “ personal failure" but was the consequence of "an enormous barrage of propaganda which serve to create what Betty Friedan called 'the feminine mystique"'. ${ }^{48}$ Many women were dissatisfied with their lives but found it difficult to pin down the problem. They had been taught that they would find happiness in marriage and motherhood and as a consequence when they felt discontented with their 'lot', they tended to blame themselves. In order to overcome these feelings of guilt, women needed to become aware of the fact that the way they lived their lives was not determined by immutable biological characteristics but dictated by socially constructed ideas that were imposed on them and veiled as natural. One way to achieve this awareness was through consciousness-raising groups.

The concept originated in the United States and the phrase was coined by Kathie Sarachild who had been inspired by Anne Forer following a group meeting during which she had compared women to working-class men. Her argument had been that just as male workers needed to be made aware of their oppression, women had to un-cover their own. Ann Forer had proceeded to ask her women friends to give examples of their own oppression so that she could raise her own consciousness. ${ }^{49}$ Kathie Sarachild had subsequently presented the idea of consciousness-raising groups at the First National Women's Liberation Conference near Chicago in $1968 . .^{50}$ The concept soon crossed the Atlantic and CR groups began to flourish in Britain. CR was understood to be a process whereby women would become aware of their own oppression and would thereby develop feminist views and practices.

Typical CR groups were small groups composed of ten to fifteen women who would take turns hosting weekly meetings in their homes. Like in any other gatherings of the WLM, there were no leaders, no hierarchies. As stated by Françoise Barret-Ducrocq, "It had been established as a dogma that there should be no hierarchies, no leaders" 51 and women were very careful not to seem to put themselves forward. In a BBC documentary Ann Oakley recalled with regret that when in 1972 her book, Sex, Gender and Society was published she did not mention it to her CR group because she did not want to appear to show off.5.$^{52}$ They talked about their personal and intimate lives, about their feelings and addressed a vast range of issues that were of direct concern to them. In a leaflet entitled "Women Awake, The Experience of Consciousness-raising", Sue Brueley listed the 17 topics that were discussed at the $\mathrm{CR}$ meetings of the Clapham group she attended in the early 1970s: our bodies, our childhood, work, relationships with men, relationships with women, love, couples, jealousy, anger, 'our greatest' fear, children, dreams, sexuality, honesty, 'positive, negative and puzzling', images of ourselves, the rest of my life. ${ }^{53}$ In most cases, the groups were closed that is to say that once formed they did not accept new members. The logic behind this rule was that $\mathrm{CR}$ was at the same time an individual and a collective process and that therefore any addition of new members would entail repetition and slow down group progress. ${ }^{54}$ More importantly, groups were meant to provide spaces for all members to express themselves and find a voice. A specific topic was chosen for each session and all members personally committed as they presented in turn and uninterrupted their personal testimonies. If initially women would feel uncomfortable about revealing intimate parts of their lives, they soon understood the benefits of engaging in such practices as it became clear that their problems were not just 
theirs. Once everyone had spoken, the group would sum up, discuss and analyse what had been said in order to draw theoretical conclusions.

Thus, if $\mathrm{CR}$ was designed to enable women to make changes in their own lives, it did not amount to therapy, as some of its detractors claimed. Its purpose was not for group members to solve their private problems but to help them discover that what they thought were failures of their own were in fact shared by other women and as such, constituted political problems that required collective solutions. For thousands of women $\mathrm{CR}$ was a crucial step in realising that they had been conditioned into believing that their primary duties were domestic ones. By sharing their private experiences and misgivings not only did women realise that they were not alone but they learnt to become more assertive and to challenge existing values. As underlined by Sue Brueley, "The most fundamental feature of the movement was the idea of 'the personal is political', that women looked to their own lives and learnt from their own experience". ${ }^{55} \mathrm{CR}$ was particularly attractive especially in the early years because it provided a frame for women to look at their personal lives and at themselves in a political way:

This meant going deep, delving into our childhood, our relationships with brothers and sisters, with our parents, what school had meant for us, how we had been brought up to view men and what future our parents had brought us up to expect $t^{56}$.

$\mathrm{CR}$ groups were women centred and encouraged their members to join in the struggle for social change at a personal and collective level. They attracted many socialist women who felt frustrated by the sexist attitude of International Socialists (IS) and other socialist groups. Sheila Rowbotham explained that

[she] found [herself] in conflict in an increasing number of particular incidents, sexual banter, the whistling when women spoke, the way in which men divided us into two, either as comrades or as women they fucked. Once a man told me to stop being so 'effeminate'. There was an argument about putting pin-ups in the Black Dwarf. I began to talk to other women. We all seemed suddenly to be feeling similar things. ${ }^{57}$

Many feminists deplored the fact that left-wing men regarded women's demands as secondary to those of working-class men and belittled CR arguing it was basically a white bourgeois middle-class approach to liberation by women who were looking for individual solutions to collective problems. The following comment by Carol Hanisch is an illustration of the tensions between feminists who put class as a primary concern and those who put women first: "Those who believe that Marx, Lenin, Engels, Mao, and Ho have the only and last 'good word' on the subject and that women have nothing more to add will, of course, find these groups [CR groups] a waste of time" ${ }^{58}$ As time went by, CR groups became more and more attractive to radical feminists, especially lesbians for whom embodied experiences of sexuality were the roots of women's oppression and who felt marginalised by socialists: "IS's denial of the place of the gay movement in any kind of revolutionary alignment convinced me of the narrowness of their politics and the basic inability of the left to take sexism seriously". ${ }^{59}$ Although many socialist women realised that not enough attention was paid to women's issues within left-wing groups they were not interested in $\mathrm{CR}$, in discussing their private lives. Like most male socialists, they believed that capitalism and the class system were responsible for the oppression of the working class and of women, however, unlike them, they were not prepared to wait for the demise of capitalism to fight patriarchy. In this perspective, they formed women's groups which addressed political issues both from a class-based and a sex-based angle. It is to be emphasised that the opposition between CR groups and socialist oriented groups 
was not as clear-cut as it would appear. Women liberationists agreed on the necessity to emancipate themselves from traditional and patriarchal values and on the fact that their bodies were their own.

What is more, despite hostile coverage in the media, the claims of the women's liberation movement struck a chord among women from all walks of life - not just feminists or socialist women - and the movement grew in size and scope. Whereas events of national dimension kept the movement in the public eye, hundreds of small groups, sometimes composed of only a few individuals, carried on forming at a local level. In many cases, these groups or workshops were co-ordinated by local Women's centres, sometimes subsidised by Labour local authority grants. For instance, in Brighton, between 1974 and 1976, a Women's centre was established in an abandoned maternity hospital and benefitted of a $£ 6,000$ grant towards renovation..$^{60}$ The aims and purposes of this growing number of women's groups were very diverse and a substantial number of them applied themselves to effective practical changes and actions. Women also took matters into their own hands and set up structures to provide help for women who needed it. The opening of the first refuge for battered wives in Chiswick, West London, in 1971, by Erin Pizzey is an example of such actions - it led to the formation of the National Women's Aid Federation in 1975; the communal or collective crèches were another example. Many were organised on a voluntary basis and some were funded by local councils as was the case of the Dartmouth Park Hill nursery in London. ${ }^{61}$

\section{Publications}

27 The underpinning of the movement was the surge in feminist publications. ${ }^{62}$ Ranging from leaflets, newspapers and magazines to all kinds of books (fiction, history, theory etc.) these writings were crucial communication tools between feminists but, equally important, they were pivotal to reaching out to women who did not feel involved in the WLM.

As underlined by Marsha Rowe ${ }^{63}$ the technical development of offset lithographic printing, which had made printing easier and cheaper, had led, in the 1960s, to the development of an "underground press" spreading a counter culture. ${ }^{64}$ In the wake of this underground press ${ }^{65}$ feminists were inspired to produce their own press organs to inform women of the WLM activities but also to make them aware of their oppression: "When Spare Rib began, we saw it as an activity and consciousness-raising process combined". ${ }^{66}$

29 At the height of the movement, scores of newsletters were produced by local groups in order to keep women informed of their activities and in 1975, at the national conference in Manchester, it was decided to set up a Women's Information and Referral Enquiry Service (WIRES) which proceeded to create a newsletter (entitled WIRES) for the movement. Its role was to collect and disseminate information pertaining to women's groups throughout the country. ${ }^{67}$

30 A number of newspapers, magazines and journals also flourished. Usually operated on a non-profit basis, they were self-financing through subscriptions, donations and fund raising. The vast majority were against commercial advertising and only promoted events, publications or sometimes goods which they deemed in keeping with feminist ideas. All welcomed contributions or testimonies from women who were not directly 
involved in the publishing and creation of the journals and their content varied and reflected the various sensibilities within the BWLM.

There were a number of left-wing newspapers which, in some cases, benefitted from the printing equipment of the political parties they were linked to. Among these, the most famous were Women's Voice (1972-1982) published by International Socialists; Red Rag (c.1973-1980) published by a Marxist collective; Link (1973-84) which was the Communist Party Women's Journal or Socialist Woman, National Paper of the Socialist Woman Groups (1969-80). ${ }^{68}$ Arena Three, published by the Minorities Research Group (1963-1972) was the first openly lesbian newspaper, it was followed by Sappho (1972-82) which became the mouthpiece of the lesbian feminists. ${ }^{69}$ Women of colour also had their own publications such as FOWAAD!, the newsletter of the Organisation of Women of Asian and African Descent (OWAAD) formed in $1978 .{ }^{70}$ However, the better known magazines were those that promoted the views of the movement in a wide ranging way. Shrew (1969-74, with additional issues between 1976 and 78) had started as a newsletter. It was London centred and could boast a circulation of about 5,000 copies. Produced each month by a different group of the London Women's Liberation Workshop, Shrew varied greatly in its political content and was a perfect illustration of the non-hierarchical and democratic ethos of the movement. ${ }^{11}$ But by far the most famous and longest lasting was the monthly magazine, Spare Rib (1972-1993) ${ }^{72}$ whose sales reached 30,000 by the mid-1970s (Pugh 322) and a national readership of about 100,000 . Unlike most other feminist newspapers which were only purchasable through subscriptions or in feminist bookshops or women's centres, Spare Rib was a newsstand magazine available through W H Smith newsagent - one of the leading news agency chains in Britain - throughout the country. The founders, Rosie Boycott and Marsha Rowe "decided to incorporate the traditional elements of women's magazines into Spare Rib, but to express them in other ways". ${ }^{73}$ The aim was to reflect a broad range of feminist views and concerns through articles on the organisation and evolution of the women's movement, on women's experiences, on women's history, on feminist theories and there was an "emphasis on first-hand accounts, written by the women involved rather than by journalists observing events from the outside". ${ }^{74}$ As its ethos was anti-consumerist it had a highly selective advertising policy.

Another key element to feminist publications was the creation of feminist presses. As for newspapers and magazines, different presses catered for different political stances. For instance, The Onlywoman Press (1974-2016), a radical lesbian feminist press was established in London; Sheba (1980-94), ${ }^{75}$ a "not-for-profit workers' co-operative" small independent publisher giving priority to marginalised women: women of colour, lesbians and workingclass women was founded in the UK. However, the most prolific and best established one was Virago (1973-present). ${ }^{76}$ Initially, it undertook to rediscover and publish books written by women at the beginning of the twentieth century but which were no longer in print. This endeavour was part of the feminist analysis whereby literary publishing was political. Starting from the realisation that there were few women authors among the great names of literature, feminists decided to reclaim women's literature. ${ }^{77}$ This led them to unveil the sexist mechanisms inherent in the androcentric bias of literary critique. It showed that, under the guise of universality, the notions of «Classic Literature » or of « literary canon » excluded women's writings from the Literary World. It is to be noted that these presses were able to rely on a widespread network of alternative and feminist bookshops throughout the country, the London based Sisterwrite (1978-1986) and Silver Moon (1984-2001) being the most famous ones. These presses were 
so successful that soon mainstream and academic publishers developed catalogues of women's books and major bookstore chains started to offer special sections devoted to women writers. Although this gynocentric approach proved very useful and efficient in promoting women's literature it has gradually been abandoned because of its essentialist basis.

\section{Conclusion} second-wave feminists had come to realise that legislation had failed to bring about the real changes they had dreamed of. Yet, despite the shortcomings of the legislation in favour of sex equality, the new laws were symbolic of the State's recognition of women's oppression and as such did play an influential role in raising awareness of discrimination which gave many women the confidence to fight for their rights. Not only did some women learn to protest and speak publicly but the vast majority realised that their dependence on men was neither natural nor inevitable. At the end of the 1970s, feminists were already able to look back at what the movement had achieved. "We feel that the women's movement has, at the very least, raised the consciousness, and encouraged the self-organization of thousands of women. In doing so it has also begun to challenge relations of power". ${ }^{78}$

$$
\text { traditional attitudes throughout the population - not just of women or feminists - and }
$$
had a profound and lasting impact on gender roles.

The 1978 Birmingham conference which led to the split in the movement at national level only marked the partial failure of second-wave feminism. With the advent of Thatcherism and neoliberalism, the 1980s saw a clear decline in socialist feminism however this did not mean the end of feminism, rather, it took on a new turn and became diversified and "fragmented", notably in the shape of liberal, radical or black feminism. It is also to be noted that by establishing the conceptual distinction between sex and gender, secondwave feminism paved the way for future developments such as those of the transgender and queer movements and studies that emerged in the 1990s.

In the same way as the suffragettes had been stigmatised as 'unnatural' women, secondwave feminists have been portrayed as "bra burners" sexually frustrated ugly man-hating individuals (spinsters or lesbians). This backlash on feminism has used and abused the excesses of a marginal minority of radical separatists who were not representative of the movement. And the fact is that nearly half a century later, very few British people still adhere to the views on the sexes that were commonly held prior to the WLM - more often than not they regard them as misogynist and sexist. If many still distance themselves from feminism, they would not, however, wish to go back on the achievements of the WLM. They say "I am not a feminist but..." and when asked to mention what feminist measure or law they disapprove of, they are at pains to find one.

Interestingly, out of the four initial demands adopted at the first national conference, the fourth one - free 24 hour nurseries - was the only demand that had not been put forward by feminists of previous generations. ${ }^{79}$ It was also the only one that did not find its way into legislation. Yet, although its aim was to enable women to work shifts, it was, possibly the most politically revolutionary one as it would have amounted to placing the 
responsibility of childcare onto the state thus freeing mothers (and fathers) from the duty of looking after their children whenever they needed it and also, crucially, enabling women's financial independence. It is to be noted that comparatively little advance has been made regarding this fourth demand, and yet, recent studies continue to show that having children puts women at a disadvantage while it benefits men: a "Fatherhood Bonus" versus a "Motherhood Penalty", but perhaps even more telling, such organisations as the Fawcett Society or the TUC, which have published reports on this subject, do not propose recommendations as daring as 24 hour nurseries ${ }^{80} . .$.

Florence Binard est maîtresse de conférences habilitée à diriger des recherches. Elle enseigne la civilisation britannique et les études sur le genre et la diversité à l'UFR EILA (Études Interculturelles en Langues appliquées), Université Paris Diderot Sorbonne Paris Cité. Elle est l'auteure d'une monographie intitulée, Les Mères de la nation : féminisme et eugénisme en Grande-Bretagne (2016).

\section{NOTES}

1. CAINE Barbara, English Feminism 1780-1980, Oxford, OUP, 1997, p.255.

2. By the year 2000, more than 3 million copies of The Feminine Mystique had been sold. www.nytimes.com (22 June 2016) Fox Margalit, «Betty Friedan, Who Ignited Cause in 'Feminine Mystique' dies at 85 », Feb 5, 2006.

3. See CAINE Barbara, English Feminism 1780-1980, op. cit., p.226; PUGH Martin, Women and the Women's Movement in Britain (1st ed.1992), London, Macmillan, 2000 (2nd edition) p.316; Rошвотнам Sheila, Woman's Consciousness, Man's World (first published in 1973), London Pelican, 1977, p.3.

4. FRIEDAn Betty, The Feminine Mystique (1963) London Penguin, 1992, p.293.

5. The protest against the Miss World beauty competition at the Albert Hall in London in 1970 with feminists throwing flour-bombs onto the stage and carrying placards with such titles as « Miss-conception », « Miss-treated », Miss-placed » etc. was an imitation of a demonstration that had taken place against the Miss America Contest in Atlantic city in 1968.

6. See HANISCH Carol, «The Personal Is Political : The Women's Liberation Classic With a New Explanatory Introduction », 2006, http://www.carolhanisch.org/CHwritings/PIP.html (22 June 2016)

7. PUGH Martin, Women and the Women's Movement in Britain, op. cit., p.318.

8. The Reform Act of 1918 granted the right to vote to women over the age of thirty. It was only in 1928 that universal suffrage became a fact in Britain.

9. Rowe Marsha, Spare Rib Reader, Harmondsworth, Penguin, 1982, p.564.

10. MAITLAND Sara, Very Heaven, Looking Back at the 1960s, London, Virago, 1988, p.54.

11. The contraceptive had pill become available to married women in 1961 and to all women in 1967. Abortion had become legal in 1967. (Timeline of the Women's Liberation Movement - The British Library, www.bl.uk/sisterhood/timeline )

12. Rошвотнам Sheila, Woman's Consciousness, Man's World, op. cit., p.6.

13. http://www.annoakley.co.uk/ (April 29, 2016).

14. Ann Oakley, Sex, Gender and Society (1972), http://www.annoakley.co.uk/ (April 29, 2016). 
15. See SEGAL Lynne, Is the Future Female? Troubled Thoughts on Contemporary Feminism (1987), London, Virago, 1991, p.x.

16. https//www.ruskin.ac.uk/about History (April 29, 2016)

17. ALEXANDER Sally, Becoming a Woman and Other Essays in 19th and 20th Century Feminist History, London, Virago, 1994, p.249.

18. See TAYLOR Ann, Women in Twentieth-Century Europe, Basingstoke, Palgrave Macmillan, 2008, p.120 or ALBERTI Johanna, Gender and the Historian, London, Routledge, 2002, p.29.

19. http://www.bl.uk/sisterhood/articles/womens-liberation-a-national-movement (June 28, 2016)

20. Rошвотнам Sheila, « My Work », paper presented 31 March 2012 at the IEC (Institut Emilie du Châtelet) conference "Quarante ans de recherche sur les femmes, le sexe et le genre », organised by BARRET-DUCROCQ Françoise, http://www.institutemilieduchatelet.org/visualisation-la-video? id_video=4 (July 2, 2016)

21. RоWвотнам Sheila, Woman's Consciousness, Man's World, op. cit., p.4.

22. Sally Alexander, Becoming a Woman, op. cit., p.99.

23. Rошвотнам Sheila, Woman's Consciousness, Man's World, op. cit., p.53.

24. STEVEnSon George, "The Women's Movement and 'Class Struggle' : gender, class formation and political identity in women's strikes, 1968-78 », Women's History Review, 2016, p.7.

25. « Night Cleaners and Women's Liberation ", Shrew, n 9/3, December 1971, p.2.

26. "The 'Woman Question' and Cleaners, Shrew, n' 9/3, December 1971, p.7.

27. http://www.wcml.org.uk/our-collections/protest-politics-and-campaigning-for-change/ grunwick/

28. Striking Women : Voices of South Asian Women workers from Grunwick and Gate Gourmet http://www.leeds.ac.uk/strikingwomen/grunwick

29. WILson Amrit, Finding A Voice: Asian Women in Britain [1978 and 1984], London Virago, 1988, p.70.

30. WILSON Amrit, Finding A Voice, op.cit., p.169-70.

31. Rowe Marsha, Spare Rib Reader, op. cit., p.590.

32. See http://www.feministarchivenorth.org.uk/chronology/1977-1.htm

33. Skegness in 1971, Bristol in 1973, Edinburgh in 1974, Manchester in 1975, Newcastle in 1976, London in 1977 and the last one in Birmingham in 1978.

34. For instance, the 1977 National WLM Conference in London was attended by three thousand women. See Rowe Marsha, Spare Rib Reader, op. cit., p.581.

35. http://www.bl.uk/sisterhood/timeline.

36. See REES Jeska, « A Look Back at Anger: the Women's Liberation Movement in 1978 ", Women's History Review, $n^{\circ}$ 3/19, July 2010, 337-356.

37. A political lesbian was defined as «a woman-identified woman who does not fuck men. It does not mean compulsory sexual activity with women », The Leeds Revolutionary Feminist Group, «Love Your Enemy? - The Debate Between Heterosexual Feminism and Political Lesbianism ", London, Onlywomen Press, 1981, p.5.

38. CAINE Barbara, English Feminism, op.cit., p.269.

39. See http://www.bl.uk/sisterhood/articles/politics-legislation-and-the-womens-liberationmovement

40. See http://www.bl.uk/sisterhood/articles/equality-work-and-the-womens-liberationmovement

41. See http://www.bl.uk/sisterhood/articles/family-children-and-the-womens-liberationmovement

42. PUGH Martin, Women and the Women's Movement in Britain, op.cit., p.331.

43. STEVEnSON George, "The Women's Movement and 'Class Struggle' », art. cit., p.5. 
44. http://www.fawcettsociety.org.uk/policy-research/the-gender-pay-gap/ (accessed 1 July 2016)

45. See PAINTER Kate, "Wife Rape in the United Kingdom », paper presented at the American Society of Criminology (1991) accessible at http://www.crim.cam.ac.uk/people/visitors/ kate_painter/

46. http://www.cps.gov.uk/publications/equality/vaw/

47. See BBC Documentary on Women's Liberation Movement https://www.youtube.com/watch? V=EOsLjbp-HV8M (accessed 10 July 2016)

48. Rошвотнам Sheila, Woman's Consciousness, Man's World, op. cit., p.3.

49. See BRownmiller Susan, In Our Time: Memoir of a Revolution, New York, Dial Press, 1999, p.21.

50. See SARACHILD Kathie, "A Program for Feminist 'Consciousness-raising' ", Notes from the Second Year: Women's Liberation, 1970, pp.78-80. http://library.duke.edu/digitalcollections/ wlmpc_wlmms01039/ (5 July 2016)

51. BARRET-DUCROCQ Françoise, Le mouvement féministe anglais d'hier à aujourd'hui, Paris, Ellipses, 2000, p.119.

52. BBC Documentary on Women's Liberation Movement https://www.youtube.com/watch? $\mathrm{v}=$ EOSLjbpHV8M

53. BRULEY Sue, Women Awake, the Experience of Consciousness-Raising, published by Sue Bruley, April 1976, pp.10-6.

54. See BRULEY Sue, «Consciousness-Raising in Clapham; Women's Liberation as 'lived Experience' in South London in the 1970s ", Women's History Reveiw, n5/22, 2013, p.717-738.

55. BRULEY Sue, « Consciousness-Raising in Clapham », art. cit., p.719.

56. BRULEY Sue, Women Awake, op. cit., p.8.

57. Rошвотнам Sheila, Woman's Consciousness, Man's World, op. cit., p.24.

58. HANISCH Carol, « The Personal is Political », art. cit., p.77.

59. BRULEY Sue, Women Awake, op. cit., p.3.

60. BRULEY Sue, « Women's liberation at the Grass Roots », Women's History Review, 2016, p.7.

61. « Not So Much a Day Nursery », Spare Rib 17, Nov. 1973. http://www.bl.uk/collection-items/ spare-rib-magazine-issue-017.

62. Wide collections of national and international material relating to the history of feminism from the 1960s to the present are held at the University of Leeds, Feminist Archive North (FAN) and at the University of Bristol, Feminist Archive South (FAS). http:// www.feministarchivenorth.org.uk/documents/FANJournals.pdf

See also, Laurel Forster, «Spreading the Word: feminist print cultures and the Women's Liberation Movement », Women's History Review, 2016.

63. Marsha Rowe was the co-founder with Rosie Boycott of the magazine Spare Rib in 1972.

64. Rowe Marsha, Spare Rib Reader, op. cit., p.13.

65. For example, Black Dwarf (1968-72) which was edited by a group of socialists and to which Sheila Rowbotham contributed or Suck, a sexual liberation newspaper whose first issue was published, in Amsterdam, by Jim Haynes and Germaine Greer in 1969 and immediately banned in the UK.

66. Rowe Marsha, Spare Rib Reader, op. cit., p.19.

67. See http://www.grassrootsfeminism.net/cms/node/533

68. Issues of Socialist Woman can be found at https://redmolerising.wordpress.com/socialistwoman/ (accessed 14 July 2016)

69. See http://www.grassrootsfeminism.net/cms/node/522.

70. More black feminist newspapers appeared in the 1980s, such as Outwrite (1982-88) was the voice of Black and $3^{\text {rd }}$ World women's struggles or Mukti (1983-87) whose target audience was British Asian women. 
71. See http://www.grassrootsfeminism.net/cms/node/520 or http://www.bl.uk/learning/histcitizen/21cc/counterculture/liberation/shrew/shrew.html 72. Spare Rib was digitised by the British Library in 2014 and is available at: http://www.bl.uk/ spare-rib. Editors of the Feminist Times (2013-2014) (http://www.feministtimes.com/) had wanted to call their magazine Spare Rib but were denied the right to use the name.

73. Rowe Marsha, Spare Rib Reader, op. cit., p.19.

74. Rowe Marsha, Spare Rib Reader, op. cit., p.21.

75. http://mith.umd.edu/womensstudies/ReferenceRoom/Publications/about-sheba-press.html

76. http://www.virago.co.uk/the-history-of-virago/

77. See for example, SHOWALTER Elaine, A Literature of Their Own: from Charlotte Brontë to Doris Lessing [1977], London, Virago, 1978.

78. WAINWRIGHT Hilary IN ROWBotham Sheila, SEGAL Lynne, WAINWRIGHT Hilary, Beyond the Fragments, Feminism and the Making of Socialism (1979), London, Merlin Press, 1980, p.2.

79. In the 19th century women such as Emily Davies were arguing in favour of the equal education of women (see DAVIES Emily, The Higher Education of Women (1866)); during the interwar period, such organisations as the Six Point Group or The Open Door Council were fighting for equal pay and equal opportunities; Marie Stopes birth control clinics were providing information on contraception and progressive figures such as Stella Browne were defending the right for women to abort (see Lesley hall, The Life and Times of Stella Browne (2011)).

80. OLCHAWSKI Jemima, Parents, Work and Care: Striking the balance, Fawcett Society, http:// www.fawcettsociety.org.uk/wp-content/uploads/2016/03/Parents-Work-and-Care-2016.pdf or CORY Giselle and Alfie Stirling, Pay and Parenthood, An Analysis of Wage Inequality Between Mums and Dads, TUC, 2016, $\quad$ https://www.tuc.org.uk/sites/default/files/ Pay_and_Parenthood_Touchstone_Extra_2016_LR.pdf

\section{ABSTRACTS}

This article aims to present the main aspects of the British Women's Liberation Movement of the 1970s. It traces the history of the movement from the first national conference held at the University of Oxford (Ruskin College) in 1970 to the last national conference held in Birmingham in 1978. It focuses on the beginnings of the movement, on its influence in the adoption and improvement of gender equality legislation in Britain and it underlines the profound changes brought about in the perception and understanding of gender roles in British society. This article stresses the importance of feminist publications in the dissemination of feminist ideas beyond feminist circles. It also insists on the crucial role of the practice of consciousness-raising in the development of feminist theories, notably in the distinction between sex and gender and in the realisation that "the personal is political".

Cet article a pour objet de présenter les principaux éléments du mouvement de libération des femmes au Royaume-Uni dans les années 1970. Il retrace l'histoire du mouvement du premier congrès national au Ruskin College, Université d'Oxford, en 1970 au dernier congrès national à Birmingham en 1978. Il s'intéresse aux débuts du mouvement, à son influence sur l'adoption de lois favorisant l'égalité femmes-hommes et il souligne son impact profond sur la perception et compréhension des rapports sociaux de sexes au Royaume-Uni. Cet article met l'accent sur l'importance des publications en matière de dissémination des idées féministes au-delà des 
cercles féministes, il insiste sur le rôle prépondérant de la pratique de prise de conscience (consciousness-raising) sur l'élaboration de théories féministes, notamment sur la distinction entre sexe et genre ou sur la prise de conscience du fait que « le personnel est politique ».

INDEX

Mots-clés: libération des femmes, féminisme, années 1970, politique

Keywords: women's liberation, feminism, 1970s, politics

\section{AUTHOR}

\section{FLORENCE BINARD}

Université Paris Diderot, Sorbonne Paris Cité 